\title{
HEALTH BEHAVIOUR CHANGES OF CUTANEOUS MELANOMA SURVIVORS IN SLOVENIA - A QUALITATIVE STUDY
}

\section{SPREMEMBE V ZDRAVSTVENEM VEDENJU BOLNIKOV Z MELANOMOM KOŽE V SLOVENIJI - KVALITATIVNA RAZISKAVA}

\author{
Mirjam ROGL BUTINA ${ }^{1 *}$, Igor ŠVAB², Barbara PERIĆ ${ }^{3,4}$, Igor BARTENJEV ${ }^{1,5}$
}

\author{
'Dermatology Outpatient Clinic Bartenjev Rogl, Derčeva 35, 1000 Ljubljana, Slovenia \\ 2University of Ljubljana, Faculty of Medicine, Department of Family Medicine, Poljanski nasip 58, 1000 Ljubljana, Slovenia \\ ${ }^{3}$ Institute of Oncology Ljubljana, Zaloška 2, 1000 Ljubljana, Slovenia \\ ${ }^{4}$ University of Ljubljana, Faculty of Medicine, Department of Oncology, Zaloška 2, 1000 Ljubljana, Slovenia \\ ${ }^{5}$ University of Ljubljana, Faculty of Medicine, Department of Dermatology, Zaloška 2, 1000 Ljubljana, Slovenia
}

Received: Aug 26, 2018

Accepted: Mar 12, 2019

Original scientific article

\begin{abstract}
Keywords:

cutaneous

melanoma, coping with stress,

Introduction: Most data related to cutaneous melanoma survivors' health behaviour comes from epidemiological studies and is predominantly concerned with safe-sun behaviour and self-examination. Data regarding other changes of health behaviour are scarce and so are qualitative studies in this realm. The aim of our research is to acquire insight into the experiences of patients with cutaneous melanoma in Slovenia. How did they react to the diagnosis, which changes did they introduce in their health behaviour and how do they assess the role of family doctors?
\end{abstract} experiences, health behaviour, qualitative research

\section{IZVLEČEK}

Ključne besede: melanom kože, obvladovanje stresa, izkušnje, zdravstveno vedenje, kvalitativna raziskava

Methods: Using the qualitative approach of collective case reports, a demographically diverse group of patients with different forms and stages of cutaneous melanoma was selected. Semi-structured interviews conducted by a psychologist were recorded and transcribed verbatim. For data processing, the approach of Qualitative Content Analysis was applied.

Results: We integrated interviewees' experiences after the diagnosis of cutaneous melanoma in several subcategories: either they did not introduce any changes or they mentioned changing their habits when exposed to the sun and performing skin self-examination; they also emphasized their ways of dealing with stress and raising awareness about melanoma among family members and friends. The role of family doctors in the prevention and care appears unclear; even contradictory.

Conclusions: We obtained insight into the experiences of Slovenian patients with cutaneous melanoma. The interviewees prioritised safe behaviour in the sun, strengthening of psychological stability and raising awareness about melanoma. Findings will be used in the creation of a structured questionnaire for national epidemiological survey.

Uvod: Večina podatkov, povezanih z zdravstvenim vedenjem bolnikov z melanomom kože, je pridobljena $\mathrm{z}$ epidemiološkimi raziskavami. Raziskave se pretežno ukvarjajo $\mathrm{z}$ varnim obnašanjem na soncu in samopregledovanjem kože. Bistveno manj poznamo druge spremembe $v$ zdravstvenem vedenju teh bolnikov, prav tako je - tudi $v$ tuji literaturi - le malo kvalitativnih raziskav na to temo. Namen raziskave je pridobiti vpogled $v$ izkušnje bolnikov v Sloveniji po diagnozi melanoma kože; kako so se odzvali na bolezen, kakšne spremembe so vpeljali $v$ svoje (zdravstveno) vedenje in kako vidijo vlogo osebnih zdravnikov.

Metode: Glede na namen raziskave je bil uporabljen pristop študije skupine primerov (angl. collective case report). Psihologinja je opravila poglobljene intervjuje z bolniki obeh spolov, različnih starosti, različne izobrazbe in z različnimi oblikami melanoma kože. Za obdelavo podatkov je bil uporabljen pristop kvalitativne analize vsebine.

Rezultati: Izkušnje in odzive bolnikov ob diagnozi melanoma kože smo strnili v več podkategorij: bodisi intervjuvanci sploh niso uvedli sprememb ali pa omenjajo spremembe pri zaščiti pred soncem in samopregledovanju kože; izpostavljajo tudi odziv na stres in osveščanje soljudi glede melanoma. Glede spreminjanja navad pri zaščiti pred soncem poleg uporabe zaščitnih pripravkov izpostavljajo predvsem fizikalno zaščito in pazljivost glede ur $v$ dnevu, ko se izpostavijo soncu. Samoopazovanje kože so le redko omenili spontano, po usmerjenem podvprašanju pa so vsi zatrdili, da ga izvajajo. Stres ob diagnozi premagujejo predvsem s krepitvijo čustvene stabilnosti in povečanjem telesne aktivnosti. Velik del intervjuvancev je ljudi okoli sebe pričel osveščati glede melanoma kože, tveganih vedenj in možnosti preventive. Vloga zdravnikov družinske medicine je nejasna, mestoma celo kontradiktorna.

Zaključek: Pridobljen je pričakovani vpogled v izkušnje slovenskih bolnikov z melanomom kože. Intervjuvanci so izpostavili varno obnašanje na soncu, krepitev čustvene stabilnosti in ozaveščanje bližnjih glede melanoma. Izsledki bodo uporabljeni pri oblikovanju strukturiranega vprašalnika za epidemiološko raziskavo, ki bo ovrednotila spremembe $v$ zdravstvenem vedenju bolnikov z melanomom kože in iskala dejavnike, ki ključno vplivajo nanje. 


\section{INTRODUCTION}

Cutaneous melanoma is one of the most common malignancies in the world. Given the possibility of aggressive metastases, it is the most dangerous form of skin cancer (1). Both the incidence (recorded or estimated) and the mortality of cutaneous melanoma are significantly higher in the more developed parts of the world (2).

In IARC estimations for 2018 , are among 20 countries most heavily burdened with melanoma, as many as 16 European countries; Slovenia (with estimated ASR 18.6) occupies the 10th place in the world and 8th in Europe (3). In the period 2011 to 2015 an average 124 persons per year died because of cutaneous melanoma in Slovenia, with the average age-standardized mortality rate in this period being 2.85 (3.50 for men and 2.33 for women) (4). 5-year survival rate in Slovenia, which was at the beginning of the 21 th century $80.4 \%$ and worse than European average (5), has substantially improved to $89.4 \%$ in the $2011-2015$ period. In the last twenty years much has been said about melanoma, but usually among professionals or in the direction from profession to population. Nowadays, these processes of communication and awareness are well established, either through everyday medical procedures or through prevention campaigns (6). However, when speaking with patients in dermatology clinics in Slovenia, we still notice much fear and little actual knowledge about melanoma (personal communication, 7).

The stage at which melanoma is detected and surgically removed is the most important factor for the prognosis of the disease and survival; prevention on primary and secondary level remains the key factor for the reduction of melanoma-rated mortality (8-12). This is especially important for melanoma survivors, who have a significantly increased (13) risk of acquiring second primary melanoma and should be repetitively counselled about the risk and about the importance of preventive health behaviour. To optimize our messages and interventions regarding preventive behaviour, it is crucial to (i) recognize what has changed in health behaviour after the diagnosis of melanoma and (ii) to understand the triggers to the changes. In the literature there is relatively little data (9-11, 14-16) regarding the heath behaviour of melanoma survivors. For the Slovenian population we have none. The aim of this qualitative part of our research is to understand how melanoma survivors in Slovenia percept the disease, how do they cope with it and how do they assess the role of the family doctor. Its key objective is the identification of changes in health behaviour after obtaining the diagnosis: what they do, what matters to them and whether they mention anything we have not thought about or learned from the literature.
Collected data is going to be used in subsequent epidemiological study (17), results of which shall help in the planning of future public health interventions in Slovenia.

\section{METHODS}

We performed a qualitative study of patients' experiences before and after the diagnosis of cutaneous melanoma; we used the approach of the collective case report. Among different approaches in qualitative research methodology, case studies are recommended when complex phenomena are to be studied within their contexts (18-20). They are the most powerful when answers on »how « and »why« are sought. Based on the literature, the collective (multiple) case studies enable the researcher to detect and explore the differences through replication of findings across cases (19-21). Regarding this, cases should be selected primarily because of their own intrinsic value (22). However, to better understand the underlying phenomenon, parallel sampling design is often applied: »the selected cases are treated as a set and their voice is compared to all other cases one at a time in order to understand better the underlying phenomenon, assuming that collective voices generated by the set of cases lead to data saturation « (23).

\subsection{Participants}

Altogether, ten patients from a dermatological outpatient clinic in Ljubljana, Slovenia were included ( 5 men, 5 women). We invited them to participate in the study during their regular medical check-up as melanoma survivors, however, they came to the interviews on the agreed term in their free time. Inclusion criteria were as follows: (i) diagnosis of cutaneous melanoma in the past (single, multiple, invasive or in situ) (ii) age $>18$ years and (iii) fluent in Slovenian language. To ensure the anticipated group diversity of parallel purposeful sampling, we invited patients from different geographical regions, educational background, age, gender and different melanoma stages. Parallels were gender and whether an interviewee had had one or multiple melanomas. In terms of time from the diagnosis, patients were limited only to the fact that at least one year had passed since the (first) melanoma. Group characteristics are depicted in Table 1. Patients were gathered in period from January 2015 until April 2015. 
Table 1. Characteristics of the participants.

\begin{tabular}{lc}
\hline & Total (men/women) \\
\hline Participants (n) & $10(5 / 5)$ \\
Age, mean (years) & $51.8(62 / 41.6)$ \\
Diagnosis * & \\
$\quad$ MIS & $8(6 / 2)$ \\
$\quad$ SSM & $19(10 / 9)$ \\
$\quad$ NM & $1(1 / 0)$ \\
One MM & $1(1 / 0)$ \\
Two or more MM/MIS & $4(2 / 2)$ \\
Duration from (last) diagnosis & $6(3 / 3)$ \\
to interview, mean (years) & $3.7(2.6 / 4.8)$ \\
\hline
\end{tabular}

*melanoma in situ (MIS), superficial spreading melanoma (SMM), nodular melanoma (NM), lentigo maligna melanoma (LM)

\subsection{Data Collection}

After patients' written approval, an independent psychologist conducted in depth interviews, their time duration was from 30 to 100 minutes, median being 38.5 minutes. Interviews were recorded and later verbatim transcribed. The guiding questions were followed by uplink sub-questions. Guiding questions were:

- What was your reaction to the diagnosis of melanoma?

- How did the diagnosis impact on your lifestyle changes?

\subsection{Data Analysis}

Acquired interviews were processed according to Qualitative Content Analysis (QCA) (21). Texts were listened to and read multiple times, based on which open codes were developed to capture emerging themes. After collecting the data, they were classified into meaningful units, which are described in a single word or a short sequence of words. Open coding was introduced as in the initial stage of data analysis in grounded theory studies (19). Unlike the grounded theory, where the ultimate purpose of open coding is to obtain categories that explain, the procedure in QCA (21) tends only to describe. In building the coding frame both approaches, inductive and deductive, were used. Part of the main subcategories were conceptually designed (deductive), based either on our experiences from work with patients or on data from the literature. However, the last two main subcategories as well as all detailed subcategories resulted from an inductive approach; through the analysis of "row data" of interviewees' experiences, the codes and themes emerged. Likewise, the part considering the role of family doctors, which emerged when listening/ reading the interviews, is mostly data driven. Only one category, "family doctor is checking patients' skin", was logically driven.
To ensure reliability of the coding, two independent researchers coded the texts. When applied to their coding, the coefficient of agreement was high (97\%). Regarding the validity, when a coding frame is mostly "data driven", as it happens in this research, "face" validity is advised (21). Validity is a measure of assessment between concept of the study and its procedure, and face validity displays the "extent to which your instrument gives the impression of measuring what it is supposed to measure" (21). The assessed face validity of the data was high, as there were no abstract or residual categories left.

According to the leading questions of the interview, data were assessed as important/relevant and classified into relevant categories.

\section{RESULTS}

Data based on interviews with 10 patients were categorized according to leading questions. As our aim was identification of experiences of patients who have been diagnosed with cutaneous melanoma, in the foreground were their reactions on the disease and changes in health behaviour they implemented.

Exploring the responses of the interviewees in terms of changes in their health behaviour led to the main category "impact of being diagnosed with cutaneous melanoma on health behaviour".

Patients' answers are depicted in Table 2. 
Table 2. The impact of being diagnosed with cutaneous melanoma on health behaviour.

\begin{tabular}{|c|c|c|c|}
\hline Main categories & Main subcategories & Detailed subcategories & Codes \\
\hline \multirow{19}{*}{$\begin{array}{l}\text { Health behaviour } \\
\text { management }\end{array}$} & No changes & & living the same way \\
\hline & Changes in sun behaviour & & use of protective creams \\
\hline & & & »different« creams \\
\hline & & & higher SPF used \\
\hline & & & physical protection \\
\hline & & & vigilance in hours \\
\hline & & & avoiding the sun \\
\hline & Changes in skin self-examination & & checks regularly \\
\hline & & & checks occasionally \\
\hline & & & checks before the medical check-up \\
\hline & & & being more attentive to the skin \\
\hline & Dealing with the stress & strengthening of mental stability & independently \\
\hline & & & with help of an expert \\
\hline & & & conversation with family/friends \\
\hline & & physical activity & stroll \\
\hline & & & intensive activity \\
\hline & & & yoga \\
\hline & Raising awareness of melanoma & & among kinship \\
\hline & & & among acquaintances \\
\hline
\end{tabular}

Several subcategories emerged. Two interviewees reported that they have not changed anything important: "I do not think that I did [change anything]. Maybe I have sorted certain things out, but basically I live exactly the same, because I was already convinced that I did not make any mistakes" (male, 55).

The rest of the subcategories were about changes in different aspects of health behaviour, where the first two, focusing on participants' attitude regarding the UV exposure and their examination of the skin and eventual changes, were expected, and they were distinctly realized in the interviews. The third subcategory is mainly speaking about coping with the stress of malignant disease: trying to (re)gain inner peace, either with work on one's mind/soul or with increased physical activity to alleviate the stress.

The last subcategory is dedicated to the care for (the important) others, raising awareness about melanoma, safe behaviour in the sun and being observant regarding the changes on one's own skin.

As expected, a large part of the interviewees became much more cautious when exposed to the sun. Most of them started practising cautious protection from UV rays, either with SPF products or with clothes: "I also wear a swimming cap, I am strictly protected... the most important is thorough protection from the sun, covered (with clothes), cream applied, this is the most important for sure, so to speak the only one..." (male, 74) or they became vigilant regarding the time of the day, when spending time outside "the most important instruction being that one is not exposed to the sun when it is at its strongest..." (male, 55). Some participants even began to avoid being outside during the day: "the fears about the sun exposure... came subconsciously... now I really go to extremes, I meet with friends at 18.00 only..." (female 29).

They also quite often mentioned the use of protective creams with chemical protection factors; either they started using them or they advanced to a higher SPF; one of interviewees started to use an alternative, "different" cream: “...I actually started using creams without any chemistry; for the face and body... there is no chemistry, everything is on mineral foundation; before (the melanoma) there was nothing of this, I thought it was not important..." (female, 47).

The issue of skin (self) examination (SSE) is somehow controversial. Namely, only three of ten participants mentioned SSE spontaneously but, after being specifically asked, all of them asserted that they perform it either 
regularly: "I do the examination myself once a month" (female, 47), occasionally, or they are generally more observant regarding their skin: "...since then [melanoma diagnosis], I have been more attentive to the moles" (female, 33).

Outstanding is the majority, who mentioned the need to alleviate the stress connected to diagnosis of cutaneous melanoma. The subcategory of strengthening of mental/ psychical stability was addressed most frequently of all categories. To most of the participants sharing their feelings and worries with relatives and friends was helpful enough: "I talked to my sister... she took a lot of care. Talking to someone who is close to you - at that time there is something gathering inside you - you have to deliver it out of yourself, to talk, to know that you are not alone. That you have somebody you trust" (female, 47). Much more rarely they used different mental techniques or obtained the help of an expert; "...there was so much of everything, I could not sleep...; I started to visit a psychiatrist... I had a feeling that I was insane and I needed a psychiatrist..." (female, 33). Quite a lot of interviewees sought relief in physical activities like yoga, intense strolling and hiking or more strenuous sports: "I am more physically active; I began working out” (female, 47).

The subcategory of raising awareness about melanoma and prevention thereof is represented quite largely - to the same extent as the subcategory about cautiousness towards UV exposure. Most of the participants were focused primarily on family members, while others were even more outspoken: “....in particular I told everybody I knew... in our family the diagnoses were somehow secret until then... so they also started to watch themselves and everybody around me visited a dermatologist" (female, 47).

Table 3. Patients' experiences regarding the role of family doctors before and after the diagnosis of cutaneous melanoma.

\begin{tabular}{ll}
\hline Categories & Codes \\
\hline Before the diagnosis & $\begin{array}{l}\text { does not deal with the skin } \\
\text { alerts about skin self-examination } \\
\text { incorrectly assesses specific lesion }\end{array}$
\end{tabular}

After the diagnosis active

passive

relieving

burdening
In the part of the research where interviewees spoke about the role of their family doctors, we designed two main categories: before and after the diagnosis of cutaneous melanoma. All the subcategories were data driven (Table 3).

A weak half of the interviewees mentioned a role of family doctor before the diagnosis of cutaneous melanoma and after it. They assessed the doctor's attitude before the diagnosis quite critically; sometimes almost angrily. They felt that she/he was not attentive enough to their skin - nobody mentioned that a check-up of the skin lesions was performed and only one participant, with positive family history of melanoma, mentioned that she was advised to self-examine her skin: »by nature I have many moles and my doctor advised me to check them " (female, 29). However, another participant, phototype 1 and with positive family history of melanoma, felt that total forsaking of skin examination was not appropriate: "for example, I regularly attend medical check-ups, do the electrocardiogram... but nobody ever mentioned skin self-examination to me» (male, 55). Two participants expressed concern and sounded apprehensive because their family doctor's diagnostic assessment was wrong, even though they themselves alerted her/him about the lesion: "... a strange lesion appeared... I showed it a few times to my doctor, but she always said: 'oh, it is nothing important'« (female, 58).

Statements regarding the role of family doctors after the diagnosis of cutaneous melanoma strike as being much less passionate; they sound more as a depiction of a relationship that a patient has with her/his family doctor. Interviewees experienced their family physician's attitude in diverse ways; as active "... he sent me to blood tests, I am under control..." (female, 47) or passive: “...l believe he is warning the patients... but ... I overtook him with the results..." (male, 74), some experienced it as relieving “... my family doctor also told me that the first level is not that dangerous..." (female, 29) and others as burdensome:" The event... which could shake someone a little... she (the doctor) automatically said, if I were visiting oncology department, if I had psychological support... I saw a question mark above her - why I was not going" (male, 55).

\section{DISCUSSION}

After they received the diagnosis of cutaneous melanoma, the vast majority of our interviewees introduced changes to their health behaviour. In accordance with beforementioned data from literature $(9-11,15,16)$, they were predominantly changing their habits regarding the sun protection. Only a part of interviewees spontaneously mentioned self-examination although, after being asked directly about the subject, everybody claimed that after the diagnosis they watch their skin more carefully. Reasons 
that self-examination was not frequently mentioned are not known. We assume that it is still a common occurrence that people connect prevention against skin cancer only with safe sun behaviour. One of the reasons may be that experts emphasize safe sun behaviour over selfexamination in the media and in personal communication with patients $(24,25)$. However, in Slovenia we heed the guidelines for management of patients with melanoma (26). Patients are rigorously monitored and counselling about safe sun behaviour and skin self-examination are regular parts of medical visits. On the other hand, it may be that patients do not trust in their own capability of recognising an atypical lesion and, as Ajzen stated (27), the limiting factor is low perceived behaviour control. This may well be connected with high fear appeal regarding melanoma in the last few decades and not (yet) strong enough efficacy messages (28).

Interviewees very often mentioned the strengthening of their psychical stability (29): usually this was achieved independently of any professional help (most often through conversation with relatives and friends), only rarely with some help from an expert. Even though there is no lack of evidence that melanoma survivors are in need of psychological support $(30,31)$, we did not find any data about specific approaches to melanoma patients. Researchers who looked into the cancer treatment in the USA in general, found that, despite the fact that the provision of psychosocial support to the cancer patients was identified as part of good medical care, health professionals often do not detect patients' need for it. As mentioned in the literature $(32,33)$, patients are rarely referred to appropriate specialists or treated according to their psychological needs.

Relatively often, interviewees mentioned the intensification of physical activity after being diagnosed with cutaneous melanoma - either outdoors or in the gym. Although the benefits of regular physical activity for melanoma patients have not been investigated, regarding the results of studies, concerning patients with other cancers (34), the benefits are expected and are emphasized in Cancer Fact Sheets (35). Regular outdoor activity after being diagnosed with melanoma is encouraged but, as Lawler and co-workers suggested (36), physical activity and sun protection should be promoted simultaneously.

More than half of our interviewees are raising awareness on the issues of cutaneous melanoma among their relatives and friends. The result is not in concordance with the report from Oliveria and co-workers (16), where even patients who understood the increased risk for family members rarely raised the issue among them.
Surprisingly, considering reports in the literature (37), not even one interviewee mentioned changes in other aspects of healthy lifestyle, like healthy eating or reducing alcohol intake and smoking.

Patients' experience on the role of family doctors is, strictly speaking, not a component of health behaviour, but already at the first interview the message had such power so that we did not label it as irrelevant; when opinions multiplied, we formed a separate part of the research. Interviewees mentioned the impact of a family doctor in the time before the diagnosis of cutaneous melanoma and, later, after the diagnosis and treatment were performed.

The results are surprising. Almost half of the interviewees think that they belong to a group with a high risk for skin cancer because of their skin type or/and abundance of moles, and two of them are burdened with a family history of melanoma. However, physicians payed no special attention to their skin; the only exception was a warning about the need of skin self-examination to one participant. Moreover, when alerted about a "suspicious" pigmentary lesion (which was later confirmed to be melanoma), the family doctor did not take it seriously.

After the diagnosis of cutaneous melanoma, the situation is somehow fragmented and unconvincing. Half of the interviewees do not even mention a family doctor or her/ his response. Others depict different situations; they are experiencing their physician as active, with relieving impact, but also as ignorant and burdening or very passive. Results are consistent with the reporting of Loescher and co-workers (38) who find that communication with people at high risk is inadequate, inconsistent or even inaccurate. Reasons are attributed to (i) the lack of time that a doctor spends with the patient, which is further reduced by all the more extensive administrative requirements, (ii) intensive sub-specialization of doctors and, consequently, lack of knowledge in areas not domiciled and (iii) lack of communication skills. However, as Hajdarević and coworkers (39) stated, healthcare providers should expand the understanding of patients' experiences and the patterns of seeking medical care. By facilitating access to medical care, early diagnostics will also be facilitated.

\subsection{Study Limitations}

We are aware of two limitations; interviews were conducted in familiar medical surroundings and half of the interviewees were regular patients of the principal investigator. Those circumstances could have influenced patients' responses. In order to diminish that influence, a psychologist who is not a member of the staff and was unknown to interviewees conducted the interviews. 
Probably we should also mention the number of participants among limitations. We are aware that many qualitative multiple case studies include 30 or more participants but, on the other side, Creswell (19) advises to use four to five cases. Only if there is a rationale does he advise to expand the group. Our rationale was diversity of interviewees. Thus, in the beginning we included 10 patients, with the intention to include more if we do not achieve saturation. However, saturation was achieved by the seventh patient and we saw no reason to expand the group.

Regarding the time interval from the last melanoma, which is different for men and women, we believe that we cannot consider it as a limitation. All interviewees could be labelled as "mature" survivors, and most probably their responses are not an acute (over)reaction to the diagnosis of melanoma but stable changes in health behaviour.

The strength of our study is its design based on the patients' experience after being diagnosed with cutaneous melanoma and possibility of detailed research of patients' perception and reaction. Moreover, the research framework was not rigid and when new information emerged the framework could be revised.

Implications for practice: findings served as a background for ongoing quantitative epidemiological survey, which is evaluating the extent of changes in health behaviour and factors that trigger those changes. Collected data will facilitate communication with melanoma patients and help to design corresponding public health interventions.

\section{CONCLUSION}

Presented qualitative research offers an insight into the experience of patients with cutaneous melanoma in Slovenia and into the changes of their health behaviour. The interviewees set in the forefront safe behaviour in the sun, dealing with stress and raising awareness about melanoma among fellow men. They mentioned skin self-examination less often. The specific role of family doctors in the prevention and care of people with high risk for melanoma appears contradictory or is at least not sufficiently defined.

\section{CONFLICTS OF INTERESTS}

The authors declare that no conflicts of interest exist.

\section{FUNDING}

The author(s) received no specific funding for this work.

\section{ETHICAL APPROVAL}

This study conforms to the recognised standards of the Declaration of Helsinki and was approved by the Republic of Slovenia National Medical Ethics Committee on 13th of May 2014 (reference number 139/05/14).

\section{REFERENCES}

1. Garbe C, Bauer J. Melanoma. In: Bolognia JL, Jorizzo JJ, Schaffer JV, Callen JP, Cerroni L, Heymann WR, et al. Dermatology. 3rd ed. London: Elsevier, 2012:1885-914.

2. Estimated cancer incidence, mortality and prevalence worldwide in 2012. Accessed August 25th, 2018 at: http://globocan.iarc.fr/Pages/ summary_table_site_sel.aspx.GLOBOCAN 2012.

3. Cancer today. Accessed September 16th, 2018 at: http://gco.iarc.fr/ today/online-analysis-multi-bars.

4. Slora. Accessed November 24th, 2018 at: http://www.slora.si/ documents/11561/20219/Melanoma.pdf.

5. Crocetti E, Mallone S, Robsahm TE, Gavin A, Agius D, Ardanaz E, et al. Survival of patients with skin melanoma in Europe increases further: results of the EUROCARE-5 study. Eur J Cancer. 2015;51:2179-90. doi: 10.1016/j.ejca.2015.07.039.

6. van derLeest RJ, de Vries E, Bulliard JL, Paoli J, Peris K, Stratigos A, et al. The Euromelanoma skin cancer prevention campaign in Europe: characteristics and results of 2009 and 2010. J Eur Acad Dermatol Venereol. 2011;25:1455-65. doi: 10.1111/j.1468-3083.2011.04228.x.

7. Leskovšek K, Ocvirk J. Malignant melanoma: awareness of malignant melanoma, risk factors and related behavior towards them among adolescents in Slovenia. Onkologija. 2018;22:68-73.

8. Azzarello LM, Dessureault S, Jacobsen PB. Sun-protective behaviour among individuals with family history of melanoma. Cancer Epidemiol Biomarkers Prev. 2006;15:142-5. doi: 10.1158/1055-9965.EPI-05-0478.

9. Mujumdar UJ, Hay JL, Monroe-Hinds YC, Hummer A, Begg C, Wilcox $\mathrm{H}$, et al. Sun protection and self-examination in melanoma survivors. Psychooncology. 2009;18:1106-15. doi: 10.1002/pon.1510.

10. Manne S, Lessin S. Prevalence and corelates of sun protection and skin self-examination practices among cutaneous malignant melanoma survivors. J Behav Med. 2006;29:419-34. doi: 10.1007/s10865-0069064-5.

11. Geller AC, Swetter SM, Brooks K, Demiere M, Yaroch A. Screening, early detection, and trends for melanoma: current status (2000-2006) and future directions. J Am Acad Dermatol. 2007;57:555-72. doi: 10.1016/j.jaad.2011.05.045.

12. Weinstock MA. Progress and prospects on melanoma: the way forward for early detection and reduced mortality. Clin Cancer Res. 2006;12:2297-300. doi: 10.1158/1078-0432.CCR-05-2559

13. Youlden DR, Youl PH, Soyer HP, Aitken JF, Baade PD. Distribution of subsequent primary invasive melanomas following a first primary invasive or in situ melanoma in Queensland, Australia, 1982-2010. JAMA Dermatol. 2014;150:526-34. doi: 10.1001/jamadermatol.2013.9852.

14. Hay JL, Buckley TR, Ostroff JS. The role of cancer worry in cancer screening: a theoretical and empirical review of the literature. Psychooncology. 2005;14:517-34. doi: 10.1002/pon.864.

15. Bowen D, Jabson J, Haddock N, Hay J, Edwards K. Skin care behaviors among melanoma survivors. Psychooncology. 2012;21:1285-91. doi: 10.1002/pon.2017.

16. Oliveria SA, Shuk E, Hay J, Heneghan M, Goulart J, Panageas K, et al. Melanoma survivors: health behaviors, surveillance, psychosocial factors, and family concerns. Psychooncology. 2013;22:106-16. doi: 10.1002/pon.2059. 
17. Zurc J. Integrating quantitative and qualitative methodology in health science research: a systematic review. Zdr Varst. 2013;52:221-35. doi: 10.2478/sjph-2013-0023.

18. Butow PN, Kazemi JN, Beeney LJ, Griffin AM, Dunn SM, Tattersall MHN. When the diagnosis is cancer. Cancer. 1996;77:2630-7.

19. Cresswell JW. Qualitative inquiry and research design: choosing among five approaches. 2nd ed. Thousand Oaks Ca: Sage, 2007:1-232.

20. Baxter P, Jack S. Qualitative case study methodology. Qualitative Report. 2008; 13: 544-59. Accessed August 25th, 2018 at: http://www. nova.edu/ssss/QR/QR13-4/baxter.pdf.

21. Schreier, M. Qualitative content analysis practice. Thousend Oaks, CA: Sage, 2013:1-244.

22. Stake RE. Case studies. In: Denzin NK, Lincoln YS, eds. Handbook of qualitative research. 2nd ed. Thousend Oaks, CA: Sage, 2000:435-54.

23. Onwuegbuzie A, Leech NL. Sampling designs in qualitative research: making sampling process more public. Qualitative Report. 2007;12:23854. Accessed August 25th, 2018 at: https://nsuworks.nova.edu/tqr/ vol12/iss $2 / 7$.

24. Montague M, Borland R, Sinclair C. Slip! Slop! Slap! and SunSmart, 1980 - 2000: skin cancer control and 20 years of populationbased campaigning. Health Educ Behav. 2001;28:209-305. doi: 10.1177/109019810102800304.

25. Day AK, Wilson C, Roberts RM. The skin cancer and sun knowledge (SCSK) scale. Health Educ Behav. 2014;41:440-8. doi: 10.1177/1090198114529129.

26. Hočevar M, Strojan P, Ocvirk J, Ahčan U, Snoj M, Luzar B. Smernice in klinična pot za obravnavo bolnikov z melanomom. Ljubljana: Onkološki inštitut, 2010:27.

27. Ajzen I. The theory of planned behavior. Organ Behav Human Decision Process. 1991;50:179-21.

28. Witte K, Allen M. A meta-analysis of fear appeals: implications for effective public health campaigns. Health Educ Behav. 2000;27:591615. doi: 10.1177/109019810002700506.

29. Spiegel D. Mind matters in cancer survival. Psychooncology. 2012;21:588-93. doi: 10.1002/pon.3067.

30. Kasparian NA, McLoone JK, Butow PN. Psychological responses and coping strategies among patients with malignant melanoma: a systematic review of the literature. Arch Dermatol. 2009;145:1415-27. doi: 10.1001/archdermatol.2009.308.
31. Hajdarevic S, Rasmussen BH, HörnstenÄsa. You never know when your last day will come and your trip will be over - existential expression from a melanoma diagnosis. Eur J Oncol Nurs. 2014;18:355-61. doi: 10.1016/j.ejon.2014.03.015.

32. Hoffman KE, MCCarthy EP, Recklitis CJ, Ng AK. Psychological distress in long term survivors of adult onset cancer: results from a national survey. Arch Intern Med. 2009;169:1274-81. doi: 10.1001/ archinternmed.2009.179.

33. Forsythe LP, Kent EE, Weaver KE, Buchanan N, Hawkins N, Rodriguez J, et al. Receipt of psychosocial care among cancer survivors in the United States. J Clin Oncol. 2013;31:1961-9. doi: 10.1200/JCO.2012.46.2101.

34. Turner RR, Steed L, Quirk H, Greasley RU, Saxton JM, Taylor SJ, et al. Interventions for promoting habitual exercise in people living with and beyond cancer. Cochrane Database Syst Rev. 2018;19:9. doi: 10.1002/14651858.CD010192.pub3.

35. Physical activity and cancer. Accessed March 2nd, 2019 at: https:// www.cancer.gov/about-cancer/causes-prevention/risk/obesity/ physical-activity-fact-sheet. on 20190302.

36. Lawler S, Sugiyama T, Owen N. Sun exposure concern, sun protection behaviors and physical activity among Australian adults. Cancer Causes Contr. 2007;18:1009-14. doi: 10.1007/s10552-007-9041-5.

37. Hawkins NA, Smith T, Zhao L, Rodriguez J, Berkowitz Z, Stein KD. Health-related behavior change after cancer: results of the American cancer society's studies of cancer survivors (SCS). J Cancer Surv. 2010;4:20-32. doi: 10.1007/s11764-009-0104-3.

38. Loecher LJ, Crist JD, Cranmer L, Curiel-Lewandrowski C, Warneke JA. Melanoma high-risk families' perceived healthcare provider risk communication. J Cancer Educ. 2009;24:301-7. doi: 10.1080/08858190902997290.

39. Hajdarević S, Hörnsten $\AA$, Sundbom E, Brulin C, Schmitt-Egenolf $M$. Patients' decision making in seeking care for suspected malignant melanoma. J Nurs Healthcare Chronic Illnes. 2010;2:164-73. doi: $10.1111 /$ j.1752-9824.2010.01057. 